\title{
FISIOLOGÍA DE LA GOAGbisiợgín de la coagulación
}

\author{
HEMOSTACIA Coagulation physiology
}

Wendy Y. González-Maldonado ${ }^{a^{*}}$, Nancy Rodríguez-Trejo ${ }^{a}$, Eloísa E. Vargas-Cano ${ }^{a}$

LAHEMOSTASIA ESEL PROCESO QUE MANTENE LA INTEGPIDAD DEUN

Abstract:SISTEMA CIRCULATOPNO CERRADO Y DE ALTA PRESION DESPLIES OE UN DANO VASCULAR

Hemostasis is the process in which the incorporation of the circulatory system after vascular damage is preserved. For didactic purposes, hemostasis is classified as primary and secondary; the first consists in the formation of the platelet plug and the second in processes that have the purpose of fibrin formationesAdrthe end of this mechanism, the so-called coagulation cascade is initiated with

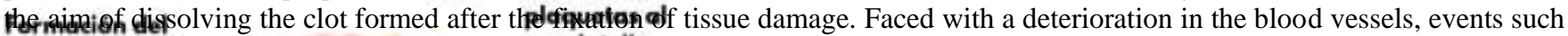
tapisadhequente.activated, which consists in thedptrolip of the platelet with the tissue; the activation and secretion that release stored substances that accelerate the formation of the Activacióp fronally the aggregation of platelets that overlap to increase coagular growth.

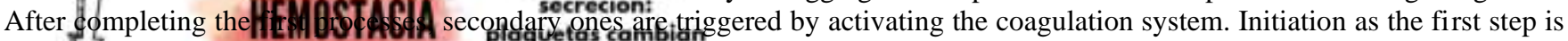
generated when thromboplastin is synthesizedsndexpressed in the cell membrane. The second step is amplification, this is obtained

PowhenóthequospholipicBRPMAPHAmbrane apeeactopatddsand release contents that form a precoagulant membrane and the final step consists of propagation, during that event hullipitegacións such as X and XI are activated transforming the prothrombin into fibrin. Both mechanisms maintain a perfect harmofneciopientestscular system, if this disappears it leads to the appearance of syndromes and alterations at the tissue level. coágulo

\section{Keywords:}

Hemostasis, thrombin, clot, tissue damage

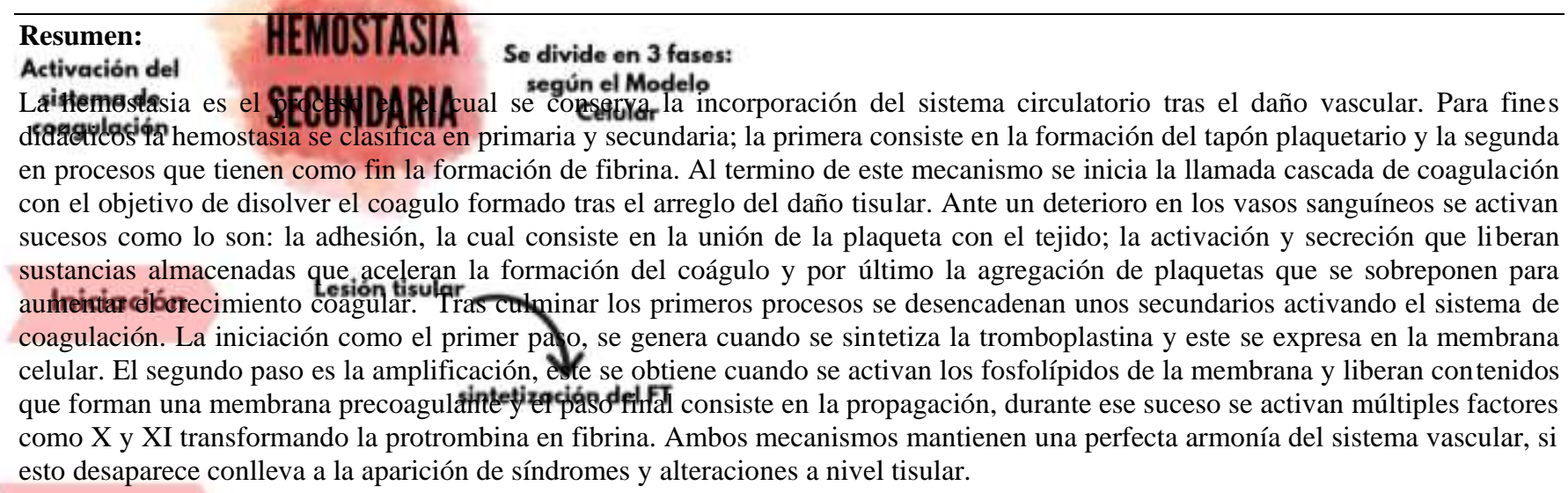

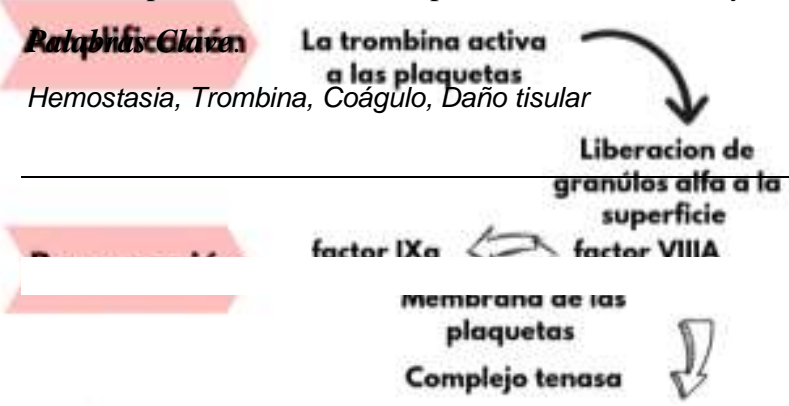

a Escuela Superior Tepeji del Rio, Licenciatura Médico Cirujano, Universidad Autónoma del Estado de Hidalgo, Av. del Maestro No.41, Col. Noxtongo 2a Sección, Tepeji del Rio, Hidalgo, México, C.P. 42855. Email: *wenglez88@gmail.com, eloisaevc@gmail.com 
Publicación semestral, Tepexi Boletín Científico de la Escuela Superior Tepeji del Río, Vol. 7, No. 13 (2020) 35-36

[1] Martínez, C.(2006). Mecanismos de acción de la coagulación, Rev, Med seguro social; 44 .

[2] Guyton, A.C. Hall, J.E. Tratado de fisiología médica. $11^{a}$ ed. Madrid: Elsevier; 2006.

[3] Baute, R.(2011).Terapia celular de la coagulación. Retomado el 18 de $\begin{array}{lccc}\text { septiembre } & \text { de } & \text { de } \\ \text { http://www.novonordisk.cl/patients/haemostatis-management/what-is- }\end{array}$ haemostasis.html

\section{Referencias}

